\title{
Plant growth, root yield and nutrients content of carrot as affected by the source of nitrogen and application of micronutrients
}

\author{
${ }^{1}$ Elwan, M. W. M.; K. E. Abd El-Hamed ${ }^{1}$; K. M. Youssef ${ }^{2}$ and M. S. S. Soliman ${ }^{1}$ \\ ${ }^{1}$ Horticulture Department, Agriculture Faculty, Suez Canal University, Ismailia, Egypt. \\ ${ }^{2}$ Food Science Department, Agriculture Faculty, Suez Canal University, Ismailia, Egypt
}

\section{Received: 6/9/2018}

\begin{abstract}
This study was carried out to give some information that could improve imported cultivars of carrot for their nutritional status and production. In this work the effect of two $\mathrm{N}$ forms (ammonium nitrate and ammonium sulphate) and two levels of micronutrients, without and with (FeEDTA+MnEDTA +MnEDTA) using two imported cultivars (Nants and Kuroda) on the growth, yield and macro and micronutrients in shoots as well as in roots were studied. The results indicated that the plant growth and yield were affected by the source of $\mathrm{N}$ and application of micronutrients, whereas generally the best results were obtained with ammonium sulphate and foliar application of micronutrients. The response of imported cultivars was quite similar. Macro and micronutrients in shoots as well as in roots were slightly affected by the genotypes, $\mathrm{N}$-forms and spraying of micronutrients with unclear trend.
\end{abstract}

Keywords: Daucus carota, N-fertilizer, macro and micronutrients, yield.

\section{INTRODUCTION}

The carrot (Daucus carota L.) is a biennial plant that has been cultivated for centuries (Rubatzky et al., 1999). Carrot is mainly grown for the fleshy pith and cortex tissues of the hypocotyl and taproot and is produced in the first year of growth. Due to the high levels of carotenoids, carrots are considered an important component of a healthy diet (Rubatzky et al., 1999) and it has gained popularity in recent years because of the increased awareness of its nutritional value Carrots do not supply a significant amount of calories to the human diet, but do supply nutrition in the form of phytochemicals, such as carotenoids, anthocyanins, and other phenolic compounds. The greatest nutritional interest in carrots comes from their phytochemical content, but research has also focused on carrots as a source of fiber. Nutrient content of carrots can vary with genotype (Nicolle et al., 2004), growing season (Horvitz et al., 2004), environmental conditions (Rosenfeld et al., 1998), and maturity stage (Phan and Hsu, 1973).

Carrot root is approximately $88 \%$ water, $1 \%$ protein, $7 \%$ carbohydrate, $0.2 \%$ fat, and $3 \%$ fiber (USDA, 2008). The carbohydrates are almost exclusively simple sugars, predominantly sucrose, glucose, and fructose, with a small amount of starch (USDA, 2008). Carrots contribute significantly to dietary vitamin A intake through $\alpha$ - and $\beta$-carotene. Carrots contain the $B$ vitamins thiamin, riboflavin, and niacin in appreciable quantities when compared with other commonly consumed vegetables. Potassium is the most abundant mineral in carrots, with a mean of $579 \mathrm{mg} / 100 \mathrm{~g}$ fresh weight. The insoluble fibers, cellulose and hemicellulose, constitute the greatest portion $(50 \%$ to $92 \%$ ) of the total dietary fiber with a very small amount of lignin (4\%). The soluble fibers consist of hemicellulose and pectin which constitute $8 \%$ to $50 \%$ of total fiber (Marlett, 1992).

Production of carrot could be increased in two ways, either by extending the area for the cultivation or by increasing the yield per unit area. The last can be done in many ways; of which the most important one is the careful application of nitrogen fertilizers and micronutrients.

Nitrogen $(\mathrm{N})$ is the most limiting nutrient for crop production in many of the world's agricultural areas and its efficient use is important for the economic cropping systems. Nitrogen has many functions in the growth and development of crop plants. Nitrogen is a component of many important organic compounds ranging from proteins to nucleic acids. It is also a constituent of compounds like chlorophyll and alkaloids. Nitrogen improves root systems, which has special significance in absorption of water and nutrients under stress conditions (Fageria, 1992). Nitrogen deficiency causes premature senescence and reduced yields (McConnell et al., 1995). When plants do not receive sufficient amounts of a nutrient to satisfy their needs, they grow poorly and develop an abnormal appearance (Grundon, 1987). Plants that are deficient in $\mathrm{N}$ will have lower photosynthetic rates and as a result, will generally accumulate less dry matter and produce lower yields (Dwyer et al., 1995; Sinclair and Horie, 1989).

For most $\mathrm{N}$ fertilizers $\mathrm{NO}_{3}^{-}$and $\mathrm{NH}_{4}{ }^{+}$are the nitrogen carriers. Ammonium is partially adsorbed on soil colloids and its uptake rate is usually therefore lower than that of $\mathrm{NO}_{3}{ }^{-}$under field conditions. For this reason, most crops do not respond as quickly to $\mathrm{NH}_{4}^{+}$ fertilizers as to $\mathrm{NO}_{3}{ }^{-}$application. Nitrate fertilizers are known to produce a rapid response in the plant in most cases. Nitrogen losses by denitrification and leaching may be higher with $\mathrm{NO}_{3}{ }^{-}$than with $\mathrm{NH}_{4}{ }^{+}$application.

In contrast to $\mathrm{NO}_{3}{ }^{-}$which is rather mobile in the soil and hardly adsorbed by soil particles, $\mathrm{NH}_{4}{ }^{+}$is adsorbed to negatively charged clay minerals because of its cationic properties. Thus, most of fixed $\mathrm{NH}_{4}{ }^{+}$is not plant-available.

Regarding the effects of nitrogen sources on carrot production, Poland scientists in Horticulture Faculty studied the effects of the sources of nitrogen on the root yield, elements contents, sugars, phenolics, vitamin C and carotene content from 2005 to 2011 using cv. Kazan F1. The results of Sady et al. (2005) showed that total and marketable yield was not affected significantly by 
the source of nitrogen (ammonium sulphate and calcium nitrate).

Micronutrients play a particular role in the growth and yield of plants. Even though these elements are needed only in minute quantities, many soils fail to supply them in adequate quantities for healthy growth of plants and optimum yield. Several workers indicated that the application of micronutrients in addition to essential major elements can play a noble role in increasing the yield of carrot (Biacset al., 1995; Grewal and Trehan, 1979; MacMillan and Hamilton, 1971; Sultana, 2012). Regarding to the micronutrients content, $\mathrm{N}$ sources (ammonium sulphate and calcium nitrate) did not affect the level of $\mathrm{Zn}$ accumulation in the root of carrot cv. Kazan F1(Smoleń and Sady, 2006). In another study (Smolen et al., 2011) using the same cultivar and four different nitrogen sources (ammonium nitrate, ammonium sulphate, calcium nitrate and urea), their results showed also the source of nitrogen did not affect the levels of thirty three elements in carrot (Fe, Zn, Mn....etc.). However, in other investigations, Smoleń and Sady (2007) and Smoleń and Sady, (2009b) using the same cultivar had the largest $\mathrm{Zn}$ and Mn contents, respectively when the carrot cv. Kazan F1 fertilized with ammonium sulphate in comparison with other Nsources (ammonium nitrate, calcium nitrate and urea). In the same direction, Smolen and Sady (2009c) stated that the $\mathrm{N}$ content and $\mathrm{N}$ uptake by the carrot roots were not affected by the source of nitrogen (calcium nitrate and ammonium sulphate). The present study was undertaken with the objective to study: 1) the effect of genotypes, nitrogen sources, micronutrients on carrot vegetative and root growth and yield. 2) The effect of genotypes, nitrogen sources, micronutrients on shoot and root macronutrients and micronutrients ( $\mathrm{Fe}, \mathrm{Zn}$ and $\mathrm{Mn})$ concentration.

\section{MATERIALS AND METHODS}

Two field experiments were carried out at the Experimental Research Farm, Faculty of Agriculture, Suez Canal University, Ismailia Governorate, Egypt, during the two successive winter seasons of 20142015(from September $28^{\text {th }}, 2014$ to January $20^{\text {th }}, 2015$ ) and repeated in 2015-2016 (from October $13^{\text {th }}, 2015$ to March $2^{\text {nd }} 2016$ ). The experiments were designed to investigate the effects of carrot genotypes, nitrogen sources, spraying of micronutrients and their interactions on plant growth, yield and macro and micronutrients concentrations.

Random soil samples were collected from 0.0-50.0 $\mathrm{cm}$ depth, before each plantation and homogenized together to determine the physicochemical characteristics of air-dried, crushed and sieved $(<2 \mathrm{~mm})$ soil in accordance to the methods of Gee and Bauder (1986) and Sparks et al. (1996). Soluble cations $\mathrm{Na}^{+}$, $\mathrm{K}^{+}, \mathrm{Ca}^{2+}$ and $\mathrm{Mg}^{2+}$ and anions $\mathrm{HCO}_{3}{ }^{-}$and $\mathrm{Cl}^{-}$were determined in the soil solution (Richards, 1954). Sulfate $\left(\mathrm{SO}_{4}{ }^{2-}\right)$ was precipitated by barium chloride as barium sulfate and gravimetrically determined (Jackson, 1967). Electrical conductivity of the saturated soil paste extract expressed as $\mathrm{dSm}^{-1}$ was measured using a conductivity meter model Jenway 3310 (Jenway Ltd., Essex,
Cambridge, UK) according to Richards (1954). Soil pH was determined by bench type Beckman glass electrode $\mathrm{pH}$ meter, in 1: 2.5 soil-water suspensions according to Page et al. (1982). Data of soil analysis are presented in Table (1).

Table (1): Soil physical and chemical properties of experimental site

\begin{tabular}{ll|lc}
\hline $\begin{array}{c}\text { Soil } \\
\text { properties }\end{array}$ & Value & \multicolumn{1}{c}{ Nutrient } & Value \\
\hline Physical & & Cations (+) & $(\mathrm{meq} / \mathrm{L})$ \\
\hline Sand & $85.21 \%$ & $\mathrm{Ca}^{2+}$ & 0.8 \\
Silt & $11.50 \%$ & $\mathrm{Mg}^{2+}$ & 0.6 \\
$\begin{array}{l}\text { Clay } \\
\text { Texture }\end{array}$ & $3,29 \%$ & $\mathrm{~K}^{+}$ & 0.3 \\
Bulk density & Sand soil & $\mathrm{Na}^{+}$ & 3.0 \\
\hline Chemical & & Anions (-) & \\
\hline SAR $($ meq $/ \mathrm{L})$ & 3.59 & $\mathrm{HCO}_{3}^{-}$ & 1.6 \\
ESP $(\%)$ & 4.34 & $\mathrm{Cl}^{-}$ & 3.0 \\
EC $\left(\mathrm{dsm}^{-1}\right)$ & 0.47 & $\mathrm{CO}_{3}^{2-}$ & 0.0 \\
pH & 8.27 & $\mathrm{SO}_{4}^{2-}$ & 0.1 \\
\hline
\end{tabular}

The experimental location was prepared before planting. During preparation, a rate of $20 \mathrm{~m}^{3}$ of cattle manure and $350 \mathrm{~kg}$ calcium super phosphate $(15.5 \%$ $\mathrm{P}_{2} \mathrm{O}_{5}$ ) per Fadden were added and then the soil of the site was cleared, ploughed, harrowed and divided into plots.

The experiment was laid-out in a split split-plot in randomized complete block design with four replicates. This experiment included twelve treatments which were the combination among two carrot genotypes (Nantes and Kuroda Improved), two nitrogen sources (ammonium sulphate 20.5\% and ammonium nitrate $33.5 \%$ ) and two concentrations of micronutrients mixture (without and with). Nitrogen was added at rate of $60 \mathrm{~kg} \mathrm{~N} /$ fed., which equivalent to about $175 \mathrm{~kg}$ ammonium nitrate or $290 \mathrm{~kg}$ ammonium sulphate per fed, respectively. The mixtures of micronutrients containing Fe-EDTA 13.5\% (one g/l) + Mn-EDTA 13\% $(0.5 \mathrm{~g} / \mathrm{l})+\mathrm{Zn}$-EDTA $14 \%(0.5 \mathrm{~g} / \mathrm{l})$ dissolved separately in water and then mixed together before spraying. The volume of sprayed solution was from $170 \mathrm{ml}$ to $200 \mathrm{ml}$ per plot each time, depending on plant development of stage. The same amount of water was sprayed to the control plants. The sprays in all cases were carried out with a manual pump.

The seeds of carrot genotypes were sown in line in the field at a depth of $1 \mathrm{~cm}$. Each plot (row) contained two lines by maintaining a distance of $25 \mathrm{~cm}$ between the lines. Plot area was one row $(6 \mathrm{~m}$ in length and 0.5 $\mathrm{m}$ in width). Emergence of seedlings was completed within10-20 days after sowing depending on the season and the genotype. Overcrowded seedlings were thinned out. Thinning of the seedlings was done twice after 6 and 8 weeks from sowing to have a uniform spacing of $5 \mathrm{~cm}$ between the plants.

Nitrogen fertilizer sources were added at five equal doses every two weeks starting after 5 weeks from the sowing. Mixture of micronutrients applied foliarly five times during growing seasons, added every two weeks starting after 6 weeks from the sowing. The soil moisture content was kept at an appropriate field capacity for sandy soil $(50-75 \%)$ as described by 
Klocke and Fischbach (1984) and Miles and Broner (1998). Weeding was done regularly to keep the plots free from weeds and to keep the soil loose and well aerated. Recommended practices for disease and insect and weed control were followed.

\section{Data collection and analysis}

Plant growth: The plant height was measured from the point of attachment of the leaves to the root (ground level) to the tip of the longest leaf at harvest by using a meter scale. The measurement was taken from the ground level to the tip of the largest leaf of an individual plant. Mean value of the six selected plants was calculated for each unit plot and expressed in centimeter (cm). Leaves were detached by sharp knife after harvest from the selected plants and their fresh weight and dry weight (in oven at $70 \mathrm{C}^{\circ}$ for $72 \mathrm{~h}$.) were taken and then their average value was recorded.

Root growth: The length of the root was measured in centimeters by a scale from the point of attachment of the leaves to the root up to the last point of the tapered end of the root. The diameter of the roots was measured using a slide calipers. The diameters of the roots were measured at harvest at the thickest part of the root. The fresh weight of carrot roots was recorded at harvest from the average of six plants in gram and then dried at $70 \mathrm{C}^{\circ}$ for $72 \mathrm{~h}$.

\section{Yield}

Harvesting of the crop was done after from 16 and 20 weeks for first and second season, respectively of sowing when the foliage turned pale yellow (Bose et al., 1990). Harvesting was done very carefully by spade. The soil and fibrous roots adhering to the tap roots were then removed.

Un-marketable yield: After harvest, the numbers of branched, cracked and doubled carrot roots were counted and the percentage of branched, cracked and doubled roots in each plot was calculated by the following formula. \% branched, cracked and doubled roots $=$ (branched, cracked and doubled roots / Number of total roots) $\times 100$

Marketable yield: The marketable yield of carrot plot was the weight of carrot roots after discarding the roots damaged by cracking, doubling and branching taken from the total yield of roots. This was recorded in kilogram per plot and then converted per fed.

Analysis of macro and micro-nutrients: Dried carrot plant parts were finely grounded. One half gram of powdered materials (leaves and roots) was digested separately for each treatment in the three replicates using a mixture of sulfuric acid and hydrogen peroxide and then brought to a final volume of $100 \mathrm{ml}$ with distilled water, to determine the following: -

- Total nitrogen (\%): Total nitrogen was estimated using semi-micro-kjeldahl method as described by Ling (1963).

- Phosphorus (\%): P was analyzed by a vanadatemolybdate method at $660 \mathrm{~nm}$ using a Spectrophotometer 220 (Chapman and Pratt, 1982).
- Potassium (\%): K was determined using a Perkinelmer, Flame photometer (Page, 1982).

- Fe, Mn and $\mathrm{Zn}$ were determined using the Atomic Absorption Spectrophotometer (Perkin-Elmer 100B).

\section{Statistical analysis}

The results were evaluated using descriptive statistics and analysis of variance (ANOVA). Using two-way ANOVA, the effect of genotypes, nitrogen sources and mixture of micronutrients foliar application as well as their interactions were evaluated by Fisher's F-test, followed by Duncan's multiple range test at 0.05 level of probability for comparing the means. All tests were performed at a significance level $\alpha$ of 0.05 . Calculations were carried out using the software package Statistica $^{\mathrm{TM}}$ for Windows version6.1 (Statsoft Inc., 2001, Tulsa, Oklahoma, USA).

\section{RESULTS}

Regarding to the main effect of genotypes, results (Table 2) revealed that the "Kuroda" genotype had significantly and greater plant height, root fresh and dry weight in the first season, however, Nantes had significantly highest root dry weight in the second season. Also, the results revealed that the "Kuroda" genotype had the significant highest shoot fresh and dry weight as well as root diameter, however, the significant highest root length was found in "Nantes" genotype in both seasons. Concerning the main effect of nitrogen sources, the illustrated results showed that no significant differences between ammonium nitrate and ammonium sulphate in case of plant height, shoot and root fresh weight, root diameter and root dry weight in both seasons, however, ammonium sulphate fertilized plants had the significant highest shoot dry weight in the first season and root length in the second season only. Generally, sprayed carrot plants with mixture of micronutrients had the highest plant growth. Whereas, the significant highest plant height (second season), shoot and root fresh weight as well as root dry weight (first season) in addition to shoot dry weight and root length (both seasons) were recorded in fertilized plants with ammonium sulphate. Non-significant differences between Kuroda and Nantes genotypes regarding to the plant height (first season), shoot and root fresh weight as well as root dry weight (second season) in addition to root diameter (both seasons).

The highest values of plant height and root diameter in the first season as well as significant highest shoot and root fresh and dry weight in the first season were found in "Kuroda" genotype using ammonium sulphate as ammonium source and in sprayed with mixture of micronutrients. Non-sprayed "Kuroda" plants fertilized with ammonium sulphate gave the highest shoot fresh weight and root diameter in the second season. The data revealed that the sprayed "Nantes" plants fertilized with both nitrogen sources gave the highest root length in both seasons. However, sprayed Kuroda plants using both nitrogen sources (AS and $\mathrm{AN}$ ) had the significant highest shoot dry weight in the first and second season, respectively (Table $2 \& 3$ ). 
Table (2): Effects of genotypes, nitrogen sources and foliar application of micronutrients on plant height, shoot fresh weight (SFW), shoot dry weight (SDW), root length and root diameter of carrot during 2014/2015 and $2015 / 2016$ seasons

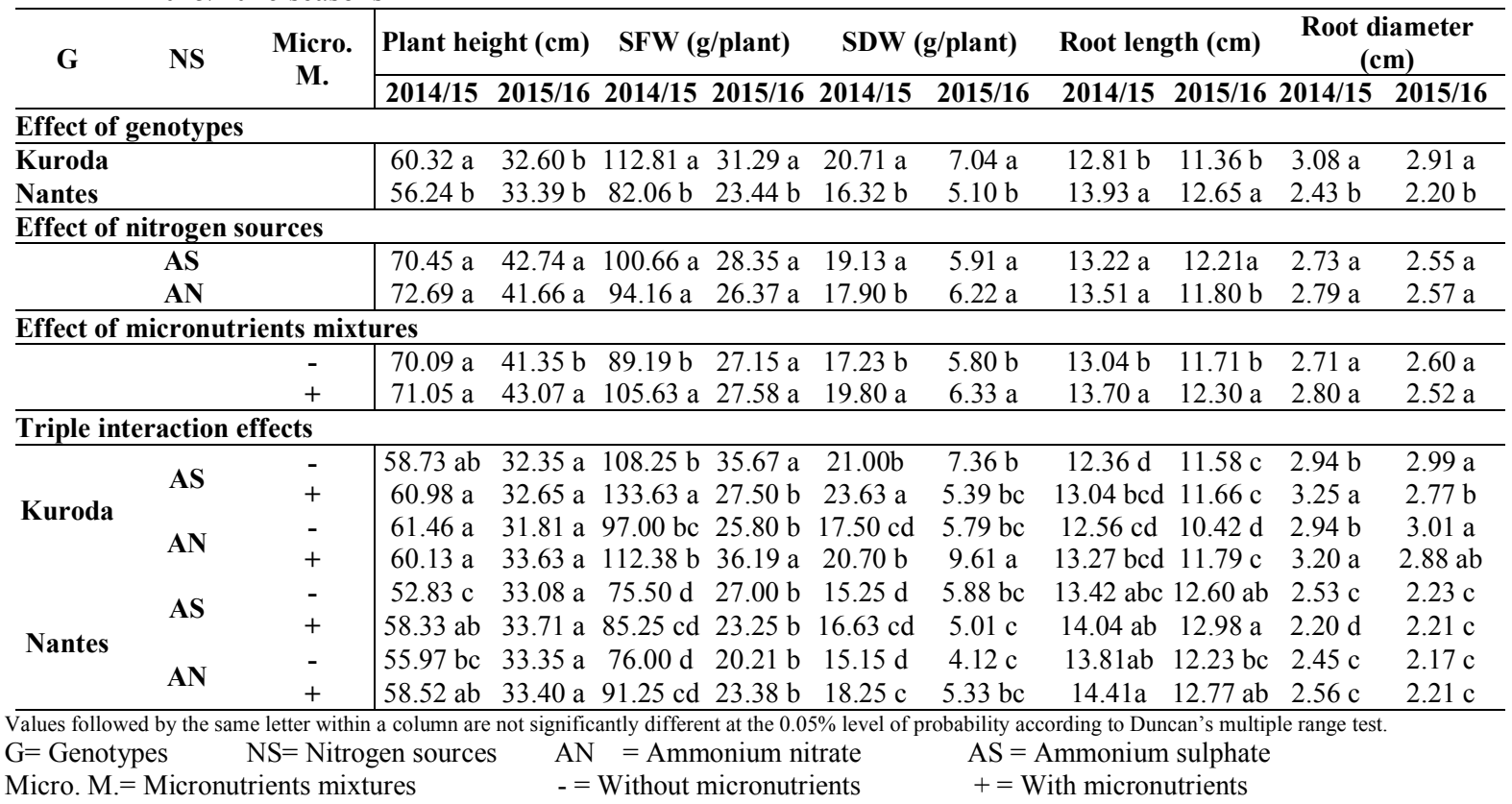

Table (3): Effects of genotypes, nitrogen sources and foliar application of micronutrients on root fresh weight (RFW), root dry weight (RDW), marketable yield, un-marketable yield and total yield of carrot during 2014/2015 and 2015/2016 seasons

\begin{tabular}{|c|c|c|c|c|c|c|c|c|c|c|c|c|}
\hline \multirow[t]{2}{*}{$\mathbf{G}$} & \multirow[t]{2}{*}{ NS } & \multirow{2}{*}{$\begin{array}{l}\text { Micro. } \\
\text { M. }\end{array}$} & \multicolumn{2}{|c|}{ RFW (g/plant) } & \multicolumn{2}{|c|}{ RDW (g/plant) } & \multicolumn{2}{|c|}{$\begin{array}{l}\text { Marketable yield } \\
\text { (t/fed) }\end{array}$} & \multicolumn{2}{|c|}{$\begin{array}{c}\text { Un-marketable } \\
\text { yield (t/fed) }\end{array}$} & \multicolumn{2}{|c|}{ Total yield (t/fed) } \\
\hline & & & $2014 / 15$ & $2015 / 16$ & $2014 / 15$ & $2015 / 16$ & $2014 / 15$ & $2015 / 16$ & $2014 / 15$ & $2015 / 16$ & $2014 / 15$ & $2015 / 16$ \\
\hline \multicolumn{13}{|c|}{ Effect of genotypes } \\
\hline Kuroda & & & $116.83 \mathrm{a}$ & $82.06 \mathrm{a}$ & $9.21 \mathrm{a}$ & $8.25 \mathrm{~b}$ & $11.02 \mathrm{a}$ & $11.29 \mathrm{a}$ & $5.03 \mathrm{a}$ & $1.90 \mathrm{a}$ & & $13.19 \mathrm{a}$ \\
\hline Nantes & & & & $79.91 \mathrm{a}$ & $6.98 \mathrm{~b}$ & $94 \mathrm{a}$ & $9.25 \mathrm{~b}$ & $9.55 \mathrm{~b}$ & $2.62 \mathrm{~b}$ & $1.52 \mathrm{a}$ & & $11.07 \mathrm{~b}$ \\
\hline \multicolumn{13}{|c|}{ Effect of nitrogen sources } \\
\hline & AS & & $100.2 \mathrm{a}$ & $80.79 \mathrm{a}$ & $8.11 \mathrm{a}$ & $8.49 \mathrm{a}$ & $10.49 \mathrm{a}$ & $10.53 \mathrm{a}$ & $4.16 \mathrm{a}$ & $1.43 \mathrm{~b}$ & $14.66 \mathrm{a}$ & $11.96 \mathrm{a}$ \\
\hline & AN & & $98.97 \mathrm{a}$ & $81.17 \mathrm{a}$ & $8.08 \mathrm{a}$ & $8.70 \mathrm{a}$ & $9.60 \mathrm{~b}$ & $10.27 \mathrm{a}$ & $3.24 \mathrm{a}$ & $2.11 \mathrm{a}$ & & $12.38 \mathrm{a}$ \\
\hline \multicolumn{13}{|c|}{ Effect of micronutrients mixtures } \\
\hline & & - & $90.51 \mathrm{~b}$ & $81.24 \mathrm{a}$ & $7.53 \mathrm{~b}$ & $8.75 \mathrm{a}$ & $8.81 \mathrm{~b}$ & $10.07 \mathrm{a}$ & $3.62 \mathrm{a}$ & $1.88 \mathrm{a}$ & $12.43 \mathrm{~b}$ & $11.95 \mathrm{a}$ \\
\hline & & + & $108.66 \mathrm{a}$ & $80.73 \mathrm{a}$ & $8.66 \mathrm{a}$ & $8.44 \mathrm{a}$ & $11.16 \mathrm{a}$ & $10.78 \mathrm{a}$ & $3.74 \mathrm{a}$ & $1.54 \mathrm{a}$ & $14.90 \mathrm{a}$ & $12.31 \mathrm{a}$ \\
\hline \multicolumn{13}{|c|}{ Triple interaction effects } \\
\hline \multirow{4}{*}{ Kuroda } & \multirow{2}{*}{ AS } & - & $110.05 \mathrm{~b}$ & $86.45 \mathrm{a}$ & $8.71 \mathrm{bc}$ & $8.99 \mathrm{a}$ & $9.60 \mathrm{~b}$ & $11.73 \mathrm{a}$ & $5.06 \mathrm{a}$ & $1.80 \mathrm{~b}$ & $14.66 \mathrm{bc}$ & $13.53 \mathrm{a}$ \\
\hline & & + & $132.88 \mathrm{a}$ & $71.35 \mathrm{a}$ & $10.72 \mathrm{a}$ & $7.01 \mathrm{~b}$ & $13.58 \mathrm{a}$ & $11.49 \mathrm{a}$ & $4.81 \mathrm{ab}$ & $0.77 \mathrm{~b}$ & $18.39 \mathrm{a}$ & $12.26 \mathrm{a}$ \\
\hline & \multirow{2}{*}{ AN } & - & $106.13 \mathrm{~b}$ & $81.76 \mathrm{a}$ & $8.00 \mathrm{c}$ & $8.54 \mathrm{a}$ & $9.77 \mathrm{~b}$ & $9.26 \mathrm{a}$ & $4.32 \mathrm{ab}$ & $3.52 \mathrm{a}$ & $14.09 \mathrm{bc}$ & $12.79 \mathrm{a}$ \\
\hline & & + & $118.25 \mathrm{~b}$ & $88.69 \mathrm{a}$ & $9.43 \mathrm{~b}$ & $8.46 \mathrm{a}$ & $10.71 \mathrm{~b}$ & $11.99 \mathrm{a}$ & $5.68 \mathrm{a}$ & $2.05 \mathrm{~b}$ & $16.39 \mathrm{~b}$ & $14.04 \mathrm{a}$ \\
\hline \multirow{4}{*}{ Nantes } & \multirow{2}{*}{ AS } & - & $78.25 \mathrm{c}$ & $82.13 \mathrm{a}$ & $6.79 \mathrm{~d}$ & $8.53 \mathrm{a}$ & $8.34 \mathrm{c}$ & $9.57 \mathrm{a}$ & $3.86 \mathrm{ab}$ & $1.36 \mathrm{~b}$ & $12.20 \mathrm{~cd}$ & $10.93 \mathrm{a}$ \\
\hline & & + & $79.63 \mathrm{c}$ & $83.25 \mathrm{a}$ & $6.24 \mathrm{~d}$ & $9.43 \mathrm{a}$ & $10.46 \mathrm{~b}$ & $9.64 \mathrm{a}$ & $2.93 \mathrm{ab}$ & $1.83 \mathrm{~b}$ & $13.39 \mathrm{c}$ & $11.47 \mathrm{a}$ \\
\hline & \multirow[b]{2}{*}{$\mathbf{A N}$} & - & $67.63 \mathrm{c}$ & $74.63 \mathrm{a}$ & $6.62 \mathrm{~d}$ & $8.93 \mathrm{a}$ & $8.09 \mathrm{c}$ & $9.37 \mathrm{a}$ & $2.00 \mathrm{~b}$ & $1.40 \mathrm{~b}$ & $10.09 \mathrm{~d}$ & $10.77 \mathrm{a}$ \\
\hline & & + & $103.88 \mathrm{~b}$ & $79.63 \mathrm{a}$ & $8.27 \mathrm{c}$ & $8.88 \mathrm{a}$ & $10.20 \mathrm{~b}$ & $9.58 \mathrm{a}$ & $2.09 \mathrm{~b}$ & $1.49 \mathrm{~b}$ & $12.29 \mathrm{de}$ & $11.08 \mathrm{a}$ \\
\hline & & & & & & & & & & & & \\
\hline Micro. M.= & & ures & & $\begin{array}{l}\text { AN }- \text { A } \\
-=\text { Withor }\end{array}$ & ut mic & & $+=$ & ients & & & & \\
\hline
\end{tabular}

Indicated results regarding to the total, marketable and un-marketable yields showed that they were affected significantly by the genotypes in both seasons. Also, the total, marketable and un-marketable yields were affected by the nitrogen sources, except only marketable and total yield in the second season and unmarketable yield in the first season were not affected significantly by the nitrogen source. Regarding to the spraying of micronutrients, the marketable and total yield were significantly affected in the first season only, however, un-marketable yield was not affected significantly by spraying of micronutrients in both seasons (Table 3 ). The presented results revealed mostly that the significant highest marketable, un-marketable and total yields were recorded in cv. "Kuroda" in both seasons. Regarding to the main effect of nitrogen source over all other tested factors, results showed that the ammonium sulphate as nitrogen source produced the significant highest marketable and total yield in the first season only. The significant highest un-marketable yield was found in carrot plants fertilized with ammonium nitrate in the second season only. The sprayed plants 
with mixture of micronutrients increased significantly marketable and total yield in the first season, however, in the second season, there were non-significant differences found between sprayed and non-sprayed plants with micronutrients. Un-marketable yield was unaffected significantly by the spraying of micronutrients in both seasons (Table 3 ).

Concerning the total and marketable yields in the second season and un-marketable yield in both seasons, they were not significantly affected by the triple interaction (GxNsxMn), however, marketable and total yield in the first season affected significantly by this triple interaction. The significant highest marketable and total yields in the first season were found in $\mathrm{cv}$. Kuroda fertilized with ammonium sulphate and sprayed with mixture of micronutrients. The non-significant lowest un-marketable yield in the second season was found in cv. Kuroda fertilized with ammonium sulphate and sprayed with mixture of micronutrients (Table 3 ).

Results regarding to shoot and root macronutrients content (Table 4) showed that the shoot N\% and shoot $\mathrm{K} \%$ were affected significantly by the genotypes in the first season only, however shoot $\mathrm{P} \%$ was not affected by the genotype in both seasons. Also, root N\% in both seasons and root $\mathrm{P} \%$ in the first season were affected significantly by the genotypes, however, root $\mathrm{K} \%$ in both seasons and root $\mathrm{P} \%$ in the second season were not affected significantly by the genotypes. Main effect of genotypes results showed that the cv. Kuroda had the significant highest $\mathrm{N} \%$ and $\mathrm{K} \%$ in the first season comparing with Nantes. However, cv. Nantes showed significant highest root $\mathrm{N} \%$ in both seasons and $\mathrm{P} \%$ in the first season comparing with cv. Kuroda. Shoot P\% in the first season and shoot $\mathrm{K} \%$ in the second season were significantly affected by the nitrogen source factor, however shoot and root $\mathrm{N} \%$, root $\mathrm{P} \%$ and root $\mathrm{K} \%$ were not affected significantly by the source of nitrogen in both seasons. Ammonium sulphate as nitrogen source was the favorable form for increasing $\mathrm{P}$ and $\mathrm{K}$ in the carrot shoots than ammonium nitrate. Also, shoot and root $\mathrm{P} \%$ in the second season and shoot $\mathrm{K} \%$ in the first season were significantly affected by the application of micronutrient, however shoot and root $\mathrm{N} \%$ and root $\mathrm{K} \%$ were not affected significantly in both seasons by the application of mixture of micronutrients compared with un-treated plants. Sprayed carrot plants with micronutrients showed highest shoot $\mathrm{P} \%$, however, unsprayed plants showed highest shoot $\mathrm{K} \%$ and root $\mathrm{P} \%$. Concerning the triple interaction (GxNsxMn), the nonsignificant highest nitrogen content in the first season was found in cv. Kuorda fertilized with ammonium nitrate without spraying of micronutrients, however, Nantes genotype fertilized with ammonium nitrate and sprayed with micronutrients had the non-significant highest nitrogen content in the second season. Regarding shoot potassium and phosphorus content, results showed mostly that the cv. Kuorda fertilized with ammonium sulphate without spraying of micronutrients gave non-significant highest values in both seasons. However, cv. Nantes fertilized with ammonium nitrate without spraying of micronutrients gave, in most cases, non-significant highest root macronutrients content (Table 4).

Table (4): Effects of genotypes, nitrogen sources and foliar application of micronutrients on shoot and root macronutrients content (NPK) of carrot during 2014/2015 and 2015/2016 seasons

\begin{tabular}{|c|c|c|c|c|c|c|c|c|c|c|c|c|c|c|}
\hline \multirow{3}{*}{ G } & \multirow{3}{*}{ NS } & \multirow{3}{*}{$\begin{array}{c}\text { Micro. } \\
\text { M. }\end{array}$} & \multicolumn{6}{|c|}{ Shoot macronutrients content } & \multicolumn{6}{|c|}{ Root macronutrients content } \\
\hline & & & & & \multicolumn{2}{|c|}{$\mathbf{K} \%$} & & & \\
\hline & & & \multicolumn{2}{|c|}{$\frac{N \%}{1 / 1520}$} & $2014 / 15$ & $\frac{P \%}{152015 / 1}$ & $2014 / 15$ & $2015 / 16$ & \multicolumn{2}{|c|}{$\frac{N \%}{2014 / 15201}$} & \multicolumn{2}{|c|}{$2014 / 152015 / 16$} & \multicolumn{2}{|c|}{$\begin{array}{c}\text { K\% } \\
2014 / 152015 / 16 \\
\end{array}$} \\
\hline \multicolumn{15}{|c|}{ Effect of genotypes } \\
\hline Kuroda & & & $3.10 \mathrm{a}$ & $2.49 \mathrm{a}$ & $0.72 \mathrm{a}$ & $0.73 \mathrm{a}$ & $6.11 \mathrm{a}$ & $2.99 \mathrm{a}$ & $2.58 \mathrm{~b}$ & $2.32 \mathrm{~b}$ & $1.16 \mathrm{~b}$ & $149 \mathrm{a}$ & $3.31 \mathrm{a}$ & $3.04 \mathrm{a}$ \\
\hline Nantes & & & $2.46 \mathrm{~b}$ & $2.73 \mathrm{a}$ & $0.75 \mathrm{a}$ & $0.70 \mathrm{a}$ & $5.08 \mathrm{~b}$ & $3.34 \mathrm{a}$ & $3.13 \mathrm{a}$ & $2.93 \mathrm{a}$ & $1.57 \mathrm{a}$ & $1.40 \mathrm{a}$ & $3.28 \mathrm{a}$ & $3.06 \mathrm{a}$ \\
\hline \multicolumn{15}{|c|}{ Effect of nitrogen sources } \\
\hline & AS & & $2.81 \mathrm{a}$ & $2.59 \mathrm{a}$ & $0.79 \mathrm{a}$ & $0.72 \mathrm{a}$ & $5.89 \mathrm{a}$ & $3.43 \mathrm{a}$ & $2.87 \mathrm{a}$ & $2.62 \mathrm{a}$ & $1.36 \mathrm{a}$ & $1.50 \mathrm{a}$ & $3.23 \mathrm{a}$ & $3.00 \mathrm{a}$ \\
\hline & AN & & $2.75 \mathrm{a}$ & $2.63 \mathrm{a}$ & $0.68 \mathrm{~b}$ & $0.70 \mathrm{a}$ & $5.30 \mathrm{a}$ & $2.90 \mathrm{~b}$ & $2.84 \mathrm{a}$ & $2.63 \mathrm{a}$ & $1.37 \mathrm{a}$ & $1.40 \mathrm{a}$ & $3.36 \mathrm{a}$ & $3.10 \mathrm{a}$ \\
\hline \multicolumn{15}{|c|}{ Effect of micronutrients mixtures } \\
\hline & & - & $2.81 \mathrm{a}$ & $2.69 \mathrm{a}$ & $0.75 \mathrm{a}$ & $0.66 \mathrm{~b}$ & $6.19 \mathrm{a}$ & $3.09 \mathrm{a}$ & $2.73 \mathrm{a}$ & $2.65 \mathrm{a}$ & $1.30 \mathrm{a}$ & $1.65 \mathrm{a}$ & $3.14 \mathrm{a}$ & $2.89 \mathrm{a}$ \\
\hline & & + & $2.74 \mathrm{a}$ & $2.53 \mathrm{a}$ & $0.72 \mathrm{a}$ & $0.77 \mathrm{a}$ & $5.00 \mathrm{~b}$ & $3.24 \mathrm{a}$ & $2.97 \mathrm{a}$ & $2.60 \mathrm{a}$ & $1.44 \mathrm{a}$ & $1.25 \mathrm{~b}$ & $3.45 \mathrm{a}$ & $3.21 \mathrm{a}$ \\
\hline \multicolumn{15}{|c|}{ Triple interaction effects } \\
\hline \multirow{4}{*}{ Kuroda } & \multirow{2}{*}{ AS } & - & $2.92 \mathrm{bc}$ & $2.67 \mathrm{ab}$ & $0.85 \mathrm{a}$ & $0.74 \mathrm{ab}$ & $6.95 \mathrm{a}$ & $3.80 \mathrm{a}$ & $2.36 \mathrm{~b}$ & $1.99 \mathrm{c}$ & $1.62 \mathrm{ab}$ & $1.90 \mathrm{a}$ & $3.05 \mathrm{a}$ & $2.35 \mathrm{~b}$ \\
\hline & & + & $3.04 \mathrm{ab}$ & $2.60 \mathrm{ab}$ & $0.69 \mathrm{ab}$ & $0.74 \mathrm{ab}$ & $6.80 \mathrm{a}$ & $3.0 \mathrm{ab}$ & $3.14 \mathrm{ab}$ & $2.49 \mathrm{abc}$ & $1.01 \mathrm{bc}$ & $1.21 \mathrm{~b}$ & $3.35 \mathrm{a}$ & $3.35 \mathrm{a}$ \\
\hline & \multirow{2}{*}{$\mathbf{A N}$} & - & $3.46 \mathrm{a}$ & $2.63 \mathrm{ab}$ & $0.61 \mathrm{c}$ & $0.66 \mathrm{ab}$ & $5.70 \mathrm{ab}$ & $2.55 \mathrm{~b}$ & $2.43 \mathrm{ab}$ & $2.24 \mathrm{bc}$ & $0.46 \mathrm{c}$ & $1.74 \mathrm{ab}$ & $3.45 \mathrm{a}$ & $3.35 \mathrm{a}$ \\
\hline & & + & $2.97 \mathrm{ab}$ & $2.08 \mathrm{~b}$ & $0.72 a b c$ & $0.76 \mathrm{ab}$ & $5.00 \mathrm{bc}$ & $2.60 \mathrm{~b}$ & $2.39 \mathrm{~b}$ & $2.55 \mathrm{abc}$ & $1.56 \mathrm{ab}$ & $1.13 \mathrm{~b}$ & $3.40 \mathrm{a}$ & $3.10 \mathrm{ab}$ \\
\hline \multirow{4}{*}{ Nantes } & \multirow{2}{*}{ AS } & - & $2.89 \mathrm{bc}$ & $2.85 \mathrm{ab}$ & $0.81 \mathrm{ab}$ & $0.62 \mathrm{~b}$ & $6.00 \mathrm{ab}$ & $3.10 \mathrm{ab}$ & $2.84 \mathrm{ab}$ & $2.93 \mathrm{abc}$ & $1.25 \mathrm{abc}$ & $1.63 \mathrm{ab}$ & $3.15 \mathrm{a}$ & $3.15 \mathrm{ab}$ \\
\hline & & + & $2.41 \mathrm{~cd}$ & $2.24 \mathrm{~b}$ & $0.81 \mathrm{ab}$ & $0.80 \mathrm{a}$ & $3.80 \mathrm{c}$ & $3.80 \mathrm{a}$ & $3.14 \mathrm{ab}$ & $3.07 \mathrm{ab}$ & $1.60 \mathrm{ab}$ & $1.26 \mathrm{~b}$ & $3.35 \mathrm{a}$ & $3.15 \mathrm{ab}$ \\
\hline & \multirow{2}{*}{ AN } & - & $1.99 \mathrm{~d}$ & $2.62 \mathrm{ab}$ & $0.74 \mathrm{abc}$ & $0.63 \mathrm{~b}$ & $6.10 \mathrm{ab}$ & $2.90 \mathrm{ab}$ & $3.30 \mathrm{a}$ & $3.74 \mathrm{a}$ & $1.90 \mathrm{a}$ & $1.34 \mathrm{ab}$ & $2.90 \mathrm{a}$ & $2.70 \mathrm{ab}$ \\
\hline & & + & $2.56 \mathrm{bc}$ & $3.21 \mathrm{a}$ & $0.66 \mathrm{bc}$ & $0.77 \mathrm{ab}$ & $4.40 \mathrm{bc}$ & $3.55 \mathrm{ab}$ & $3.23 \mathrm{ab}$ & $2.30 \mathrm{bc}$ & $1.58 \mathrm{ab}$ & $1.39 \mathrm{ab}$ & $3.70 \mathrm{a}$ & $3.25 \mathrm{ab}$ \\
\hline
\end{tabular}

The significance showed that the shoot Mn affected significantly by the genotypes in the second season, where cv. "Kuorda" had the higher value comparing with cv. Nantes. Nitrogen source affected significantly shoot Fe content in the first season, the data proved that ammonium nitrate gave the highest shoot Fe content than ammonium sulphate (Table 5). Regarding to the effect of spraying of micronutrients, results showed that shoot and root $\mathrm{Fe}$ concentrations were affected significantly by spraying of micronutrients in the second 
season and first season, respectively. The data revealed that the sprayed plants had the significant lowest Fe content in the shoots and roots of carrot. Results (Table 5) showed that measured micronutrients ( $\mathrm{Fe}, \mathrm{Mn}$ and Zn) were not significantly affected by the triple interaction in both seasons, except only shoot $\mathrm{Mn}$ content which affected significantly by the triple interaction in the second season only. Regarding to the triple effect, the results indicated that the highest shoot $\mathrm{Fe}$ content was measured in cv. Kuorda plants received ammonium nitrate and sprayed with micronutrients in the first season, however, cv. Nantes received also ammonium nitrate without application of micronutrients had the highest shoot Fe content in the second season. Non-sprayed (micronutrients) cv. Kuorda plants had the highest shoot $\mathrm{Mn}$ and $\mathrm{Zn}$ content when received ammonium sulphate in both seasons as soil fertilizer. However, combination among cv. Nantes, ammonium sulphate and spraying of micronutrients had the significant highest value of root $\mathrm{Mn}$ in the second season only.

Table (5): Effects of genotypes, nitrogen sources and foliar application of micronutrients on shoot and root micronutrients content (Fe, Mn, Zn) of carrot during 2014/2015 and 2015/2016 seasons.

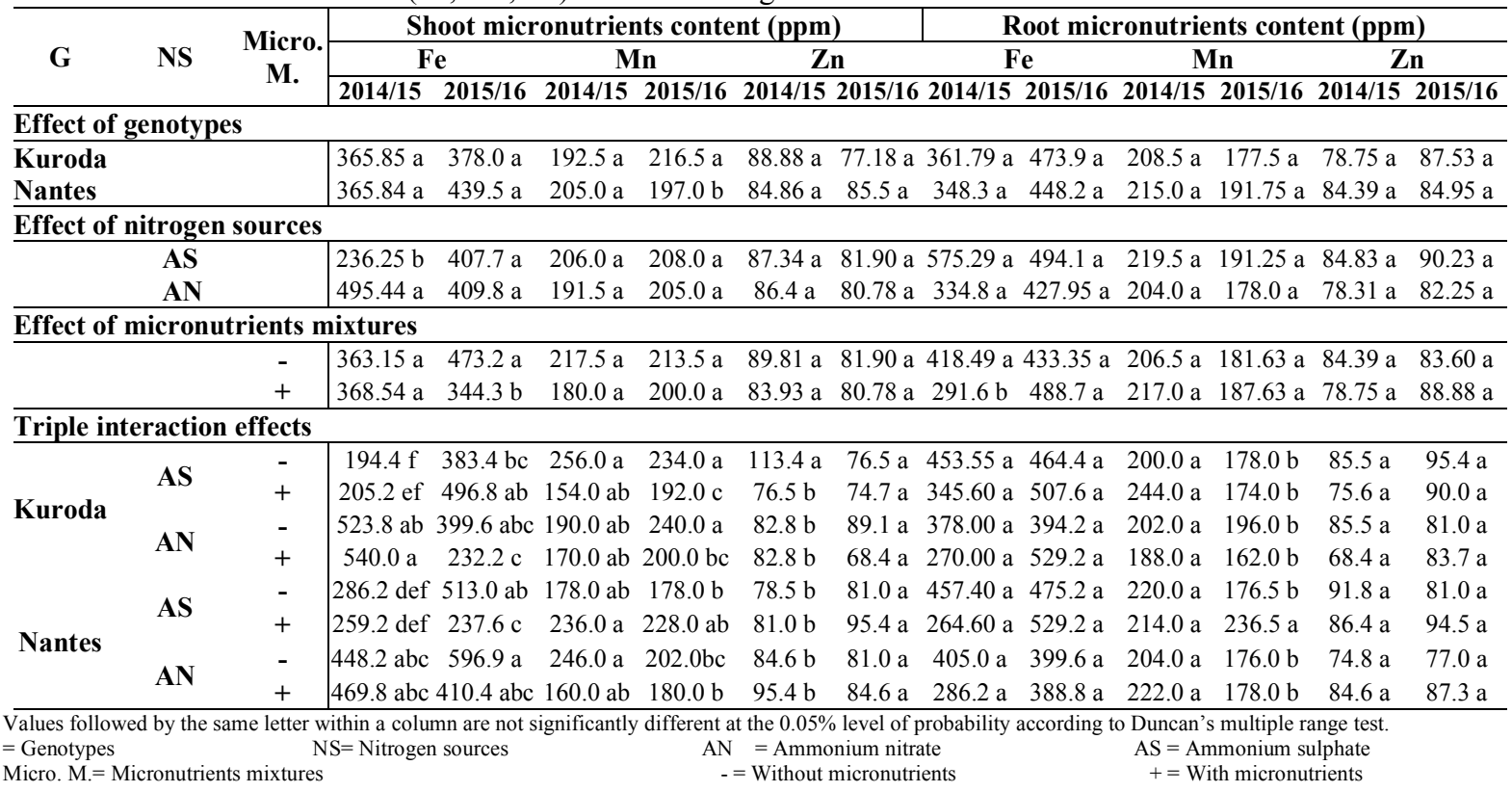

\section{DISCUSSION}

Previous literature examined the effect of nitrogen fertilizer rate on growth and yield of carrot. However, the effect of different nitrogen forms on growth and development of carrot was scarcely been reported. The nitrogen source affects numerous physiological processes including $\mathrm{N}$-assimilation, root respiration (Matsumoto and Tamura, 1981), water relations (Ragab, 1980), photosynthesis (Siddiqi et al., 2002), and secondary metabolism (Wang and Below, 1996).

Even though, it has been well documented that most plants species grow better with $\mathrm{NO}_{3}{ }^{-}$than with $\mathrm{NH}_{4}{ }^{+}$ (Barker and Mills, 1980; Salsac et al., 1987), there is also evident that plants supplied with $\mathrm{NH}_{4}{ }^{+}$can be more reproductive than those supplied with $\mathrm{NO}_{3}{ }^{-}$(Heeb et al., 2005).

Moreover, compared to plants supplied with nitrate, ammonium initially slowed the growth of shoots more than roots in Beta vulgaris (Raab and Terry, 1994). This can to some extent, explain the superiority of the ammonium fertilization on carrot compared to nitrate fertilization. In Beta vulgaris, ammonium reduced the area expansion of leaves and the relative water content but increased the leaf weight which was associated with a doubling chloroplast volume and 4.3-fold higher accumulation of soluble protein (Raab and Terry, 1994).
Although, ammonium nutrition decreased the rate of expansion of leaf surface but did not decrease the rate of photosynthesis per area and in fact, net photosynthetic $\mathrm{CO}_{2}$ exchange rate were slightly higher than in nitrate plants (Raab and Terry, 1994).

Numerous research efforts documented the advantage of nitrate nutrition over ammonium nutrition on plant growth (Barker and Mills, 1980; Salsac et al., 1987). However, Heeb et al., (2005) suggested that ammonium is an equivalent nitrogen source for tomato plants compared to nitrate. Same conclusion was achieved in many literatures especially when ammonium is supplied at reasonable levels, and together with appropriate levels of other macro-and micronutrients (Bloom, 1997; Gill and Reisenauer, 1993; Wiesler, 1997; Siddiqi et al., 2002; Gerendas et al., 1997).

The variety also affects dry matter (DM) content. The percentage differences in DM between lowest and highest contents in a study of varieties by Kreuzmann et al., (2008) were 13\% for orange-colored varieties and $60 \%$ for mixed colors. Carrots of mixed colors in a study by Bajaj et al., (1980) showed $27 \%$ difference in DM between the cultivars with highest and lowest levels.

Furthermore, Claussen and Lenz (1995) showed that vegetative and reproductive growth of eggplants may be 
manipulated by supplying ammonium nitrogen as long as the age of the plants, carbohydrate reserves of the roots, quantity of ammonium nitrogen supplied, and $\mathrm{pH}$ of the growth medium are favorable.

Despite the fact that benefits of nitrate nutrition were previously described by many researchers, however, much of this research was conducted in hydroponic studies using nutrient solution. This may partially elucidate the failure of nitrate nutrition in our study to show its superior performance due to the huge difference between nutritional solution and soil as growing medium for plants. The conflicting results in the literature concerning ammonium and nitrate appear to be at least due to the experimental conditions.

Many conditions may be affecting sensitivity of plants to ammonium nitrogen nutrition. $\mathrm{pH}$ in the root rhizosphere appear to play an important role. Many plants including (bean, sweet corn, cucumber and pea) grow without toxicity symptoms only if the $\mathrm{pH}$ in the growing medium was maintained near neutral state (Maynard and Barker, 1969). More recently, Lasa et al. (2001) reported that plant response to continuous ammonium nutrition is species dependent as spinach was highly sensitive while pea was tolerant.

It is well documented that high concentrations of ammonium nitrogen may lead to an accumulation of toxic amounts $\mathrm{NH}_{4}^{+}$ions in the plant. However, conditions supporting a rapid detoxification of ammonium nitrogen in the roots (such as a neutral $\mathrm{pH}$ ) in the rhizosphere (Barker et al., 1966) and sufficient carbohydrate reserves in the root (Givan, 1979) contribute to prevent transport of ammonium to the shoot which is considered to be more sensitive to ammonium accumulation than is the root (Barker and Mills, 1980).

If accumulation of $\mathrm{NH}_{4}{ }^{+}$ions occurs in the shoot this may lead to a decrease in net photosynthesis and may reduce growth and yield (Britto and Kronzucker, 2002). Lasa et al., (2001) also suggested that the site of ammonium assimilation is a key factor controlling tolerance to ammonium nutrition in the different plant species, with plants being more tolerant when ammonium is assimilated in root.

When ammonium sulphate is added to soil in the alkaline soil, the ammonium ion is released and forms a small amount of acid, lowering the $\mathrm{pH}$ balance of the soil (Yagodin, 1984). It has been determined that most nutrients are optimally available to plants within slightly acidic soil solution. Changes in the rhizosphere $\mathrm{pH}$ have important consequences including the availability or solubility of nutrients such as $\mathrm{P}, \mathrm{Fe}, \mathrm{Mn}, \mathrm{Zn}, \mathrm{Cu}$ and $\mathrm{Al}$ (Gahoonia, 1993). Buffer capacities of soil and root activity are the main factors influencing the soil $\mathrm{pH}$ (Youssef and Chino, 1989).

Sulfur is an essential nutrient for plants and plays a significant role in their life. (Eriksen et al., 2004). Nitrogen and sulfur are the only two fertilizer elements that are constituents of amino acids and subsequently proteins and enzymes. Biswas and Tewatia (1991) indicated that most crop species have higher yield and better quality products when there is an abundant amount of sulfur available in the soil.

Sulfur deficiency inhibits the growth and development of plants and considerably reduces crop yields. Sulfur is a constituent of amino acids, such as methionine, cystine and cystein which are essential components of protein molecules. Sulfur is also present in vitamins, such as thiamine and biotin which play a key role in plant metabolism. Thiamine is a constituent of some enzymes catalyzing decarboxylation of organic and amino acids while biotin takes part in deamination and decarboxylation of certain amino acids. Consequently, sulfur plays a major role in carbohydrate and nitrogen metabolism in plants (Yagodin, 1984).

In our experiment, a comparison has been made between ammonium nitrate (N,P,K,S - 33.5,0,0,0) and ammonium sulphate (N,P,K,S - 20.2,0,0,24) as a nitrogen source for carrot growth and yield. The results indicated that carrot produce more yield with ammonium sulphate. These results can be partially explained based on the previous discussion concerning the role of sulfur on plant growth beside its function in reducing soil $\mathrm{pH}$. Ammonium sulphate contain substantial amount of sulfur, Zhou et al., (2005) found that fertilization with NPK and sulfur significantly increased carrot yield by $17.6 \%$ with high quality.

Another trend that can explain the supremacy of ammonium over nitrate in particular cases is related to energy expenditure. Ammonium assimilation into plant metabolites requires less energy than nitrate assimilation, as it does not need to be reduced (Bloom, 1989). Heeb et al., (2005) showed that ammonium was a very effective source of nitrogen for tomato plants when applied in an $\mathrm{NO}_{3}{ }^{-}: \mathrm{NH}_{4}{ }^{+}$ratio of $1: 4$. This may suggest that plants may save energy by taking up reduced nitrogen. It is then possible that the energy saved may be used for increased production of secondary metabolites. This could result in higher plant yield and improved fruit quality and taste.

Our results failed to show significant differences between treatments due to nitrogen form concerning the shoot and root content of minerals (Fe, Mn, $\mathrm{Zn}$ ) (Fe was significantly different in shoot in one year with ammonium nitrate). These results are in total agreement with results of Smolen et al. (2011) concerning Fe and Mn. However, in results of Smolen and Sady (2009a) $\mathrm{Mn}$ resulted from ammonium sulfate showed lower Mn compared with other nitrogen sources (calcium nitrate, ammonium nitrate, and urea).

\section{CONCLUSION}

Interaction between ammonium sulphate and spraying of micronutrients improved marketable yield especially in "Kuroda" cultivar. Generally spraying of micronutrients did not improve the root content of nutrients.

\section{REFERENCES}

Bajaj, K.L., G. Kaur and B. S. Sukhija (1980). Chemical composition and some plant characteristics in 
relation to quality of some promising cultivars of carrot (Daucus carota L.). Qual. Plant Foods Hum. Nutr., 30:97-107.

Baker, A.V. and H.A. Mills (1980). Ammonium and nitrate nutrition of horticultural crops. Hort Rev. 2:395-423.

Barker, A.V., R.J. Volk and W. A. Jackson (1966). Root environment acidity as a regulatory factor in ammonium assimilation by the bean plant. Plant Physiol. 41(7): 1193-1199.

Biacs, P. A., H. G. Daood and I. Kadar (1995). Effect of Mo, Se, $\mathrm{Zn}$, and $\mathrm{Cr}$ treatments on the yield, element concentration, and carotenoid content of carrot. J. Agric. Food Chem. 43(3): 589-591.

Biswas, B. C. and R. K. Tewatia (1991). Role of sulphur in balanced plant nutrition: Indian experience. In: S. Portch (ed.): Proceedings of the International Symposium on the Role of Sulphur, Magnesium and Micronutrients in Balanced Plant Nutrition. The Potash and Phosphate Institute of Canada, 98-106.

Bloom, A.J., R.M. Caldwell, J. Finazzo, R.L. Warner and J. Weissbart (1989). Oxygen and carbon dioxide fluxes from barley shoots depend on nitrate assimilation. Plant Physiol. 91(1):352356.

Bose, T.K. and M.G. Som (1990). Vegetable crops in India. Kalyani Publishers, Naya Prakash, India, p.409.

Britto, D.T. and H.J. Kronzucker (2002). $\mathrm{NH}^{4+}$ toxicity in higher plants. J Plant Physiol. 159(6):567584.

Chapman, H.D and P.F. Pratt (1982). Methods of analysis for soils, plants and water; Chapmann Publisher; Riverside, CA.

Claussen, W. and F. Lenz (1995). Effect of ammonium and nitrate on net photosynthesis, flower formation, growth and yield of eggplants (Solanum melongena L.). Plant Soil. 171(2):267-274

Dwyer, L.M., D.W. Stewart, E. Gregorich, A.M. Anderson, B.L. Ma and M. Tollenaar (1995). Quantifying the nonlinearity in chlorophyll meter response to corn leaf nitrogen concentration. Canadian J. Plant Sci. 75(1): 179-182.

Eriksen, J., K. T. Kristensen and M. Askegaard (2004). Plant availability of catch crop sulfur following spring incorporation. J. Plant Nutr. Soil Sci. 167(5): 609-615.

Fageria, N.K. (1992). Maximizing crop yields. Marcel Dekker, New York, NY.

Gahoonia, T. S. (1993). Influence of root-induced $\mathrm{pH}$ on the solubility of soil aluminum in the rhizosphere. Plant and Soil. 149(2): 289-291.
Gee, G. W. and J. W. Bauder (1986). Particle-size analysis. In Methods of soil analysis, ed. A. Klute, 383-409. Madison, Wisc.: ASA and SSSA.

Gerendás, J., Z.I. Zhu, R. Bendixen, R.G. Ratcliffe, B. Sattelmacher (1997). Physiological and biochemical processes related to ammonium toxicity in higher plants. Z Pflanzenernähr Bodenkd 160(2):239-251.

Gill, M. A. and H. M. Reisenauer (1993). Nature and characterization of ammonium effects on wheat and tomato. Agron. J. 85:874-879.

Givan, C.V. (1979). Metabolic detoxification of ammonia in tissues of higher plants. Phytochemistry, 18:375-382.

Grewal, J.S. and S.P. Trehan (1979). Micronutrients requirement of carrot crop. Ann. Sci. Rep., CPRI, India, 49-50.

Grundon, N.J. (1987). Hungry crops: a guide to nutrient deficiencies in field crops. Queensland Dep. Primary Indus. Brisbane.

Heeb, A.; B. Lundegardh, T. Ericsson and G. P. Savage (2005). Nitrogen form affects yield and taste of tomatoes. J. Sci. Food Agric. 85(8): $1405-$ 1414.

Horvitz, M.A., P.W. Simon and S. A. Tanumihardjo (2004). Lycopene and $\beta$-carotene are bioavailable from lycopene 'red' carrots in humans. Eur. J. Clin. Nutr., 58:803-811.

Jackson, M.L. (1967). Soil Chemical Analysis. Prentice Hall Inc., Englewood Cliffs, N.J., Library of Congress, USA.

Klocke, N.L. and P.E. Fischbach (1984). Estimating Soil Moisture by Appearance and Feel. University of Nebraska-Lincoln Extension. G84-690.

Kreutzmann, S., A. K. Thybo, M. Edelenbos and L. P. Christensen (2008). The role of volatile compounds on aroma and flavor perception in coloured raw carrot genotypes. Int. J. Food Sci. Technol. 43: 1619-1627.

Lasa, B., S. Frechilla, C. Lamsfus and P. M. AparicioTejo (2001). The sensitivity to ammonium nutrition is related to nitrogen accumulation. Sci. Horti. 91(1): 143-152.

Ling, E.R. (1963). Determination of total nitrogen by semimicrokjeldahl method. Dairy Chem. 11: 23-84.

MacMillan, K.A. and H. A. Hamilton (1971). Carrot response to soil temperature and copper, manganese, zinc and magnesium. Canadian J. Soil Sci., 51(2): 293-297.

Marlett, J.A. (1992). Content and composition of dietary fiber in 117 frequently consumed foods. J. Am. Diet. Assoc. 92:175-186. 
Matsumoto, H. and K. Tamura (1981). Respiratory stress in cucumber roots treated with ammonium or nitrate nitrogen. Plant Soil. 60: 195-204.

Maynard, D. N. and A. V. Barker (1969). Studies on the tolerance of plants to ammonium nutrition. J. Am. Soc. Hort. Sci. 94: 235-239.

McConnell, J.S., R.E. Glover, E.D. Vories, W. H. Baker, B.S. Frizzell and F.M. Bourland (1995). Nitrogen fertilization and plant development of cotton as determined by nodes above white flower. J. Plant Nutr. 18(5): 1027-1036.

Miles, D.L. and I. Broner (1998). IRRIGATION, Estimating Soil Moisture. Colorado State University Extension Crop Series. No. 4.700.

Nicolle, C., G. Simon, E. Rock, P. Amouroux and C. Rémésy (2004). Genetic variability influences carotenoid, vitamin, phenolic, and mineral content in white, yellow, purple, orange, and dark-orange carrot cultivars. J. Am. Soc. Hortic. Sci., 129(4):523-529.

Page, A.L., R.H. Miller and D.R. Keeney (1982). Methods of Soil Analysis. Part 2: Chemical and Microbiological Properties. ASA, Madison, WI.

Phan, C.T. and H. Hsu (1973). Physical and chemical changes occurring in the carrot root during growth. Can. J. Plant Sci., 53:629-634.

Raab, T.K. and N. Terry (1994). Nitrogen-source regulation of growth and photosynthesis in Beta vulgaris L. Plant Physiol., 105: 11591166.

Ragab, S. M. (1980). Water uptake and trans-potential in sunflower roots as influenced by ammonium ions. J. Agri. Sci. 94:145-150.

Richards, L.A. (1954). Diagnosis and improvement of saline and alkali soils. US Salinity Lab., US Department of Agriculture Handbook 60 . California, USA.

Rosenfeld, H.J., R. T. Samuelsen and P. Lea (1998). The effect of temperature on sensory quality, chemical composition and growth of carrots (Daucus carota L.) I. Constant diurnal temperature. J. Hort. Sci. Biotechnol., 73:275288.

Rubatzky, V. E., C. F. Quiros and P. W. Simon (1999). Carrots and related vegetable Umbelliferae. New York.

Sady W., S. Smoleń and S. Rożek (2005). Effect of differentiated nitrogen fertilization and foliar application on yield and biological quality of carrot crop. Horticulture and Vegetable Growing 24 (3): 273-281.

Salsac, L., S. Chaillou, J. F. Morto-Gaudry, C. Lesaina and E. Jolivet (1987). Nitrate and ammonium nutrition in plants. Plant Physiol. Biochem. 25:805-812.

Siddiqi, M. Y., B. Malhotra, X. Min and A. D. M. Glass (2002). Effects of ammonium and inorganic carbon enrichment on growth and yield of a hydroponic tomato crop. J. Plant Nutr. Soil Sci. 165: 191-197.

Sinclair, T.R. and T. Horie (1989). Leaf nitrogen, photosynthesis and crop radiation use efficiency: a review Crop Sci. 29(1):90-98.

Smoleń, S. and W. Sady (2006). The content of Cd, Cu and $\mathrm{Zn}$ in carrot storage roots as related to differentiated nitrogen fertilization and foliar nutrition. Pol. J. Environ. Stud. 15(2a): 503509 .

Smoleń, S. and W. Sady (2007). The effect of nitrogen fertilizer form and foliar application on $\mathrm{Cd}, \mathrm{Cu}$ and $\mathrm{Zn}$ concentrations in carrot. Folia Hort. 19(1): 87-96.

Smoleń, S. and W. Sady (2009a). The effect of various nitrogen fertilization and foliar nutrition regimes on the concentrations of sugars, carotenoids and phenolic compounds in carrot (Daucus carota L.). Sci. Hort., 120:315-324.

Smoleń, S. and W. Sady (2009b). The effect of nitrogen fertilizer form and foliar application on the concentrations of twenty-five elements in carrot. Folia Hortic. 21(1): 3-16.

Smoleń, S. and W. Sady (2009c). The effect of various nitrogen fertilization and foliar nutrition regimes on the concentrations of nitrates, ammonium ions, dry matter and $\mathrm{N}$-total in carrot (Daucus carota L.) roots. Sci. Hortic. 119(3): 219-231.

Smoleń, S., W. Sady and J. Wierzbińska (2011). The effect of various nitrogen fertilization regimes on the concentration of thirty three elements in carrot (Daucus carota L.) storage roots. Vegetable Crops Res. Bull. 74: 61-76.

Sparks, D. L., A. L. Page, P. A. Helmke, R. H. Loeppert, P. N Soltanpour, M. A. Tabatabai, C.T. Johnston and M. E. Sumner (1996). Methods of soil analysis. Madison, Wisc.: ASA and SSSA.

Statsoft, Inc. (2001). STATISTICA fuer Windous [Software-system fuer Daten analyse] Version 6. www.Statsoft.com.

Sultana, M.N. (2012). Response of carrot to different micronutrients (Doctoral Dissertation), Bangladesh Agricultural University.

USDA National Nutrient Database for Standard Reference, Release 21. (2008). Composition of Foods Raw, Processed, Prepared. Available from:http://www.nal.usda.gov/fnic/foodcomp/searc $\underline{\mathrm{h} /}$ 
Wang, X. and F. E. Below (1996). Cytokinins in enhanced growth and tillering of wheat induced by mixed nitrogen source. Crop Sci. 36: $121-126$.

Wiesler, F. (1997). Agronomical and physiological aspects of ammonium and nitrate nutrition of plants. J. Plant Nutr. Soil Sci. 160: 227-238.

Yagodin, B. A. (1984). Agricultural Chemistry (Part 1). Mir Publishers, Moscow. pp. 375.

Youssef, R. A. and M. Chino (1989). Root-induced changes in the rhizosphere of plants. I. $\mathrm{pH}$ changes in relation to the bulk soil. Soil Sci. Plant Nutr. 35(3): 461-468.

Zhou Y., D. Wang, J. Zhu, Q. Liu and M. X. Fan (2005). The role of sulfur fertilizers in balanced fertilization. In: L.J. De Kok and E. Schnug (eds.), Proceedings of the $1^{\text {st }}$ SinoGerman Workshop on Aspects of Sulfur Nutrition of Plants, 23 -27 May 2004, Shenyang, China, Landbauforschung Völkenrode, 283:171-176.

\section{النمو النباتي،محصول الجذور ومحتوى العناصر في الجزر تأثر بمصدر السماد النيتروجيني والرش بمخلوط العناصر الصغزى

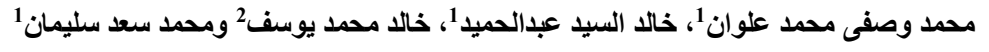 \\ 1 قسم البساتين - كلية الزراعة ـ جامعة قناة السويس - الإسماعيلية ـ مصر

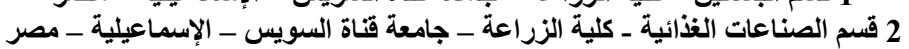

أجريت هذه الدر اسة لإعطاء بعض المعلو المات مات و التي بدور ها ستساعد على تحسين أصناف الجزر المستوردة وذللك فيما يتعلق بمحتو اها الغذائي

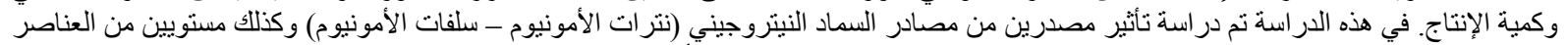

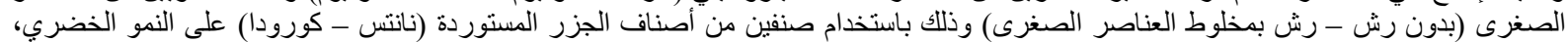

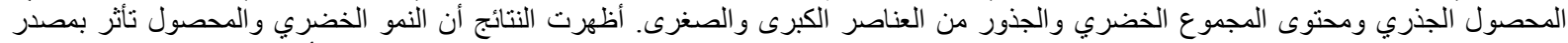

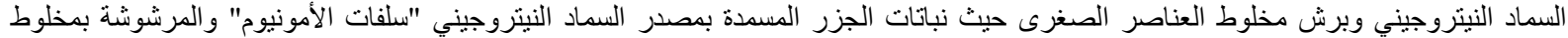

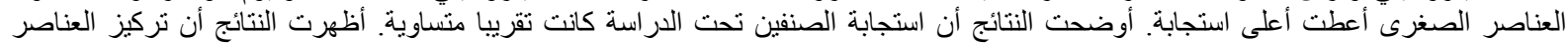

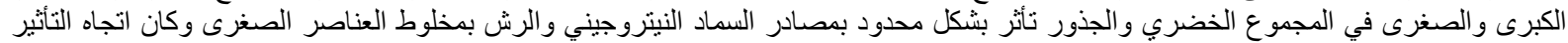
غير و اضح.

الكلمات الدالة: ـ الجزر - السماد النيتروجيني، العناصر الكبرى والصغرى، المحصول. 